\title{
Emitter Device
}

National Cancer Institute

\section{Source}

National Cancer Institute. Emitter Device. NCI Thesaurus. Code C49937.

The electron source electrode in a transistor or any source in a system. 